\title{
Peasant Resilience and Stakes in Crop Cultivation Within an Unstable Bio-Physical Milieu: The Case of Bui Division, North West Region, Cameroon
}

\author{
Godwill Tobouah Nyanchi ${ }^{1,}$ *, Mbanga Lawrence Akei ${ }^{2}$, Frankline Nghobuoche ${ }^{1}$, Tassah Ivo Tawe ${ }^{1}$, \\ Nkiene Valery Antu ${ }^{1}$, Mkong Unity Ghekendeh ${ }^{3}$ \\ ${ }^{1}$ Department of Geography, University of Yaoundé, Yaoundé, Cameroon \\ ${ }^{2}$ Department of Geography and Planning, University of Bamenda, Bamenda, Cameroon \\ ${ }^{3}$ Department of Sociology, University of Yaoundé, Yaoundé, Cameroon
}

Email address:

goddy288@yahoo.com (G. T. Nyanchi),nghobuochefrank@gmail.com (F. Nghobuoche), nkienevaleryantu@yahoo.com (N. V. Antu), unity.mkong@yahoo.fr (M. U. Ghekendeh)

${ }^{*}$ Corresponding author

\section{To cite this article:}

Godwill Tobouah Nyanchi, Mbanga Lawrence Akei, Frankline Nghobuoche, Tassah Ivo Tawe, Nkiene Valery Antu, Mkong Unity Ghekendeh. Peasant Resilience and Stakes in Crop Cultivation Within an Unstable Bio-Physical Milieu: The Case of Bui Division, North West Region, Cameroon. American Journal of Environmental Protection. Vol. 10, No. 2, 2021, pp. 37-52. doi: 10.11648/j.ajep.20211002.11

Received: August 4, 2020; Accepted: May 7, 2021; Published: May 20, 2021

\begin{abstract}
Prospects of food crop cultivation and supply center on peasant resilience and their adaptability to the surrounding bio-physical milieu. Farmers' predisposition to the numerous challenges within their biophysical context makes them resilient and thoughtful in strengthening their skills. The soils, relief, climate and vegetation of Bui Division heighten farmers' resilience for harmonious, flourishing and innovative techniques to hold the farmers spellbound in their daily farm operations. In addition, vegetables are cultivated abundantly in wetland areas during the dry season. Research results were tested using the relationship between the independent, dependent and the intervening variables of this study. To best operationalize this results, the Chi square and cumulative response rates were strictly applied in the analysis. Research findings revealed that the indigenes spare no effort in ensuring that the milieu is exploited to the fullest, thus reaping the benefits of their hard work. As a matter of fact, agriculture remains the dominant pre-occupation of the locals, however subsidiary activities are not neglected to make ends meet. Peasant dynamism in crop cultivation is central to their social and economic development, thus fostering their adaptability to the bio-physical setting. Crops cultivated include maize, beans, solanum potato, sweet potato, cassava, plantains, banana and yams.
\end{abstract}

Keywords: Resilience, Crop Cultivation, Bio-Physical Milieu, Sustainable Agriculture

\section{Introduction}

The hope for the future in terms of food crop cultivation within the study area lies in farmers' resilience and their ingenuousness to modern techniques. The rugged nature of the landscape designs farmlands on hills, slopes and low lying areas thus beautifying the entire mosaic background of the area. To boost food crop cultivation, the stakes and challenges depends on farmers' pliability to innovation, with an adequate regard to their bio-physical setting. Local resilience and attachment in this domain is beyond doubt recognized as a major source of increased output, alleviate poverty, competitiveness, improved income and accompanied economic growth within the area.

Agricultural research with its dynamic sphere of innovations strives to homogenously increase output. From time immemorial, agricultural activities have been undergoing innovations in many stages. In Oku, the defunct Kilum Mountain Forest Project (KMFP) brought in various plant species and the project opened demonstration farms in which farmers were trained on how to better manage the new species. Modern methods of farming alongside improved seedlings were also introduced. Unlike in the past where 
many crops were planted on one ridge, modern methods of planting encourage few crops planted at regular intervals to promote healthy growth. Each crop requires different amounts and types of nutrients, maximum sunlight and soil nutrients for their growth. In addition, more attention is paid to the maintenance of the crops. Farmers on their part are highly encouraged to weed, prune, water, mulch and spray when the right time comes. Nowadays, the farmers have realized the importance of farm maintenance and no farmer neglects his crops on the farm strengthening resilience. At each stage in the farming process, the farmer simply acts accordingly in respect to the agricultural calendar thus making acquired knowledge practical.

\section{Research Methodology}

The methodology adopted by this research meticulously answers questions peasant resilience and stakes in crop cultivation. The central theme of this work calls for an interdisciplinary approach.

\subsection{Secondary Sources}

\subsubsection{Documentary Research}

Research was conducted in specialized institutional libraries namely; ICRAF, IITA, CAMGEW, MINADER, IRAD, IRD, FASA, NACU Ltd, HPI, OACU Ltd, OHS, SHUMAS, CREX, FAO, IFAD, NGOs, and the defunct KMFP documents. Documents consulted included; reports, research findings, publications, textbooks, seminar papers. Universitylibraries included; the Faculty of Arts Letters and Social Science library in the University of Yaoundé 1, library of the University of Bamenda and University of Dschang.

\subsubsection{Council Documentary Research}

In the quest for valuable information concerning peasant resilience, council libraries were of great importance. In this light, Council Development Plans (CDP) was consulted. Council libraries included; Jakiri council library, Mbiame Council library, Oku Council library, and the Kumbo Urban Council library.

\subsubsection{Maps}

Maps conceived and properly drawn form a representation of geographical realities. Maps encompass the modification of information in such a way that it can be represented on a smaller surface. Different maps within the study area were studied and taken into consideration. These maps greatly guided the orientation of this piece of research work in terms of the physical environment, administration of questionnaires and other vital aspects on the landscape.

\subsection{Primary Methods of Data Collection}

\subsubsection{Field Observation}

Reconnaissance surveys were carried out within these SubDivisions. This included visits to the field to get original information. In this case, the researcher observed the populations with less interaction on farming activities carried out. This included uncountable visits to the study area, visits to farms and markets. Village market days are once a week and on these days the researchers visited the weekly village market for a better appraisal of the quality of food crops displayed for sale. This phase was carried out between in 2016, March 2017, June 2018 and November 2019.

\subsubsection{Participant Observation}

In this case the researcher participated actively in farming activities during the survey. This was through assisting farmers in their daily activities such as clearing, sowing, weeding, harvesting and storage of food crops, buying food crops in local markets, developmental projects within the society, gathering fuel wood and searching for medicinal plants in the forest.

\subsection{Field Data Collection}

Data collection focused on peasant activities in response to the nature of the bio-physical milieu. This involve the study of both explicit and the local tacit cultural knowledge of the farmers. Quantitative data collection was based on the collection of statistics related to agriculture, livestock (training seminar) and forestry within the study area. In this research, quantitative findings gathered facts in terms of inputs, output, and adaptation techniques of innovation, farming population, frequencies, prices and statistics.

\subsubsection{Qualitative and Quantitative Field Gatherings}

This involves the entire process of collecting field data in different forms, places and time. Secondary information was collected through official reports, interviews, questionnaires etc. The data gathered from primary and secondary sources were both qualitative and quantitative.

\subsubsection{Key Informants}

The key informant included local men and women leaders who have social and economic influence in the community. They provided information on farming practices, planting of trees, crop growing, use of trees, sources of inputs, sale of crops, activities of financial institutions, funding etc.

\subsection{Questionnaire Administration}

Questionnaires were administered to the local farmers to cross-check the results gotten from field observations. The approach for sample selection used depended on the household and residential setting in the areas. The questionnaire enhanced personal contact with respondents so that additional information for the survey could acquire. The questionnaires were designed to identify and farming operations liable to maintain resilience. They would also determine common land management practices or socio cultural characteristics of small-scale farmers.

\subsection{Interviews}

The content of the interview instrument raised questions patterning to the different resilient techniques in the area. An interview guide was used to obtain pertinent data and 
information from the heads of institutions resource persons that were visited. Secondary data from publications was used to draw on past experiences and milestones in shaping the study for better interventions in future.

\subsection{Focus Group Discussions (FGD)}

For the sake of this study, FGD targeted farmers CIGs, NGOs, cooperative and state organized events in the area. Participation in the above group activities provided the opportunity to listen to farmer's ideas, financial contributions and diverse opinions on resilient techniques. This method gave the author the opportunity to define what is relevant and important in understanding farmer's experiences. Attention was focused on the general assessment of farmer's impressions. These groups were valuable in offering an understanding (insight) of views that farmers have about specific issues on innovations as well as how they interact and discuss the issues.

\section{Results}

The results obtained revealed that peasant resilience and stake holders in crop cultivation is gaining grounds within an unstable bio-physical milieu. It was also realized that attention centered on farmers' ideas on maintaining and improving food crop production. Field gatherings make public the fact that farming techniques are rather acquired and not inherited. As a result, peasants within the study area are exposed to numerous challenges that empower them thus keeping the flames of hard work alive. In a nutshell, peasant perceptions to resilient techniques are yielding positive results.

\section{Bio-Physical Setup: Challenges and Prospects for Food Crop Cultivation}

\subsection{Heterogeneous Soil Types for Food Crop Cultivation}

\subsubsection{Ferrallitic Soils}

Ferrallitic soils are found on the low plateaus of the SubDivisions of Mbiame, Mbokam, Djottin and Nkor. These areas have humic soils derived from volcanic rocks of different ages. Volcanic soils are pyroclast at the early or advanced stage of weathering (pouzzolanes, blocs, scories ...). They can mostly be identified in Menchum Division and in low quantities in the divisions of Boyo, Bui, Donga Mantung and Mezam [1]. These soils greatly differ in their degree of fertility and in different quantities in the specific areas. Soil fertility plays a vital role in peasant adaptability and resilience in carrying out their different farming operations. The soils are formed from the ancient basaltic and trachy-ryolitic rocks. Soils found on ancient basalts cover the division stretching from Jakiri to Nkambe and extend from Kumbo to Mbiame. The soils derived from this rock basement are affected by age making the soils easily leached after intensive cultivation. Figure 1 shows the soil distribution in Bui Division.

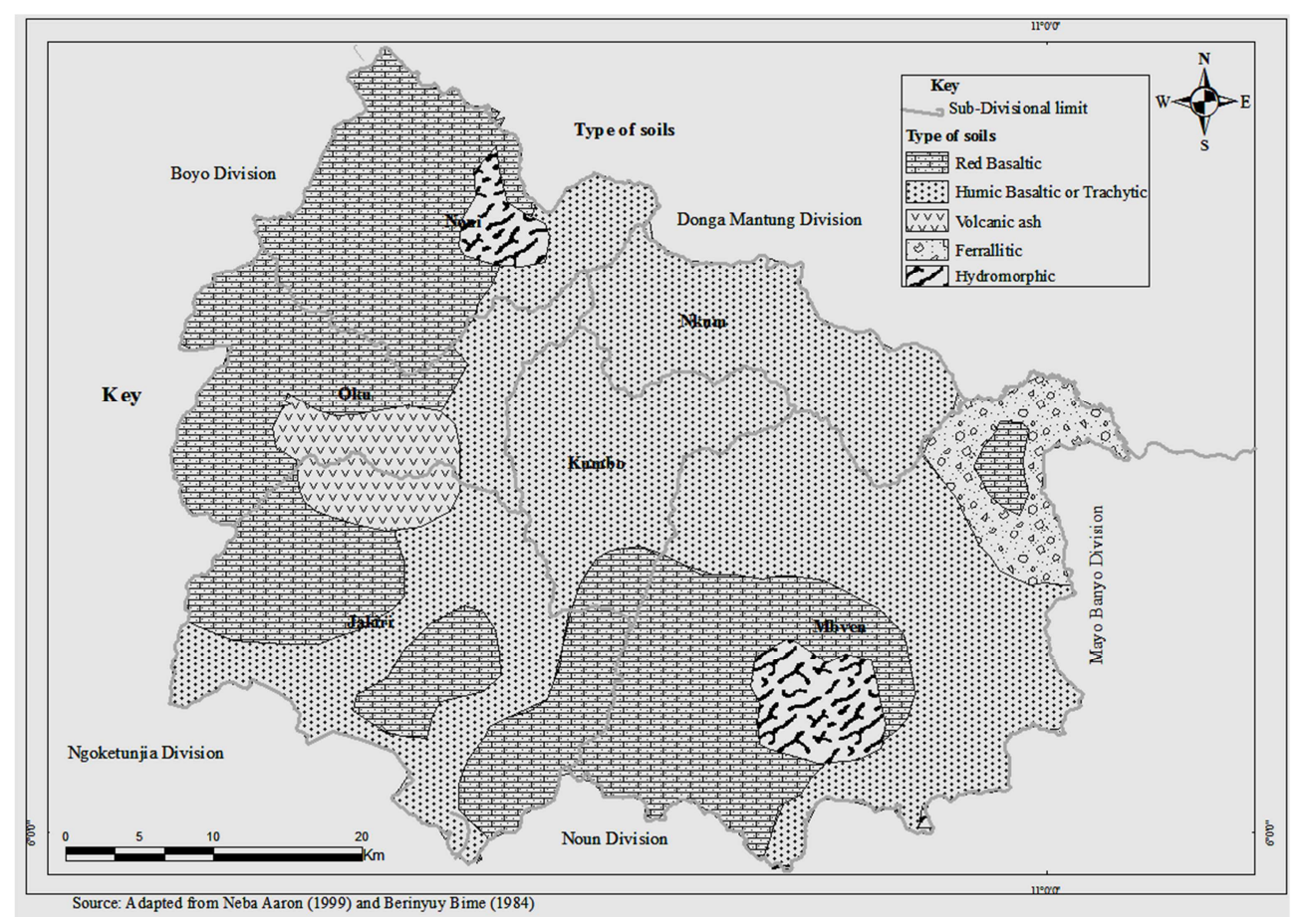

Figure 1. Soil distribution map of Bui Division.

In Bui and parts of Oku, the nature of the slopes on which ferralitic soils are found affects the fertility. On the upland slopes like on the flanks of Mount Oku, soils are interspersed with pebbles, red stones and granites. On the slopes of Mount $\mathrm{Oku}$, these soils are suitable for the cultivation of coffee and other tree crops such as avocado, oranges, mangoes and 
banana, thus attracting the interest of the peasants. Low plateau areas stretching from Nkar through Mensai right up to Nkuv passing through Shishong in Kumbo, soils are suitable for the cultivation of crops such as maize, beans, cassava, ground nuts and sugar cane.

Soils found on trachyryolitic rocks are found partly in Oku Sub-Division and in Nkor in Noni Sub-Division. Forest soils in $\mathrm{Oku}$ are dominated by trachytic soils making farmers' adaptability a greater challenge. This category is made up of deep profiles with high clay content. These soils are suitable for the cultivation of food crops such as beans, maize, potatoes, yams and cassava. On these soils, less fertilizer application is used as the farmers largely depend on their fertility. These are deeply weathered soils of fine texture and structure. Trachytic soils are humid with high carbon and organic matter content found in Nkor plains at about $1500 \mathrm{~m}$ and in Oku at an altitude of $2000 \mathrm{~m}$ and $2600 \mathrm{~m}$ [2]. The fertility of these areas attracted the population to open farms for the cultivation of basic food crops. The pressure exerted on these soils is definitely high as it is rich in chemical content favoring diverse crop cultivation.

\subsubsection{Basaltic Soils}

Basaltic soils are found in Jakiri and cover all of Kumbocentral extending to the North East. Pockets of heavily leached basaltic soils are found in Kumbo and parts of Mbokam plains in Mbiame. These soils are well drained, reddish in colour, granular in shape, with moderately deep profiles and have high silt content. Traditional farming systems with the practice of constant burning and destruction of vital soil nutrients rapidly leads to depleting soil nutrients in these areas. Farmers' resilience and challenges pinpointed the dangers of burning the soil and destroying important nutrients, thus confounding output. The deep nature of upland soils is ideal for the cultivation of the numerous food and tree crops within Bui Division. Generally speaking, altitude soils within the study area are suitable for the cultivation of crops thanks to farmers' resilience [3].

\subsubsection{Hydromorphic Soils}

Over the past years, hydromorphic soils have been considered the best and most commonly exploited soils within the division. They are found in two different relief regions in the area; the river valleys on the plateau and the plains in Lassin and in Mbo-Nso. On numerous upland valley areas, hydromorphic soils are deep, dark and swampy. On these soils are found long stretches of raffia palm bushes suitable for palm wine tapping. In other areas, the soils are covered with gallery forest. Table 1 shows soil types and averages within the study area.

Table 1. Soil Types, Average Altitudes and Characteristics in Bui Division.

\begin{tabular}{|c|c|c|c|}
\hline Average altitude (m) & Soil types & SoilCharacteristics & Areas found \\
\hline Plains: 900-1500m & Hydromorphic soils & Upland valleys: deep, dark and swampyPlains: & Lassin, Mbo-Nso \\
\hline $1500-1800 \mathrm{~m}$ & Ferralitic soils & $\begin{array}{l}\text { Humic soils, volcanic rocks, fertile, trachy-ryolitic, deep profiles, high } \\
\text { clay content, deeply weathered soils, fine texture and structure, humid, } \\
\text { high carbon and organic matter }\end{array}$ & $\begin{array}{l}\text { Mbiame, Tatum, parts of } \\
\text { Jakiri, Kumbo }\end{array}$ \\
\hline $1800-2000 \mathrm{~m}$ & Basaltic & $\begin{array}{l}\text { Well drained, reddish in colour, granular in shape, moderately deep } \\
\text { profiles, high silt content }\end{array}$ & Vekovi, Tadu \\
\hline $2000 \mathrm{~m}$ and above & Volcanic ash soil & Humiferous, brown, cemented ash pyroclast, stony & Slopes of Mount Oku \\
\hline
\end{tabular}

Source: Adapted from BerinyuyBime, (1984) and Field survey, 2018.

More than $75 \%$ of the different soil types within the study areas are found in the highland region thus demanding more efficient cultivation methods. The soils present fertile characteristics suitable for food and cash crop growth thus making resilience a challenge to the stakes of production. The application of fertilizer to soils in the area is an impetus to boost output. Types of fertilizers used include; manure, composting, mulching, liming and inorganic fertilizers. Economic restrictions limit the use of inorganic fertilizers for a majority of the small-scale farmers. Pockets of sandy, clay, loam, sandy loam, gravel light soils, humus and alluvial soils are found in plains. Their colors range from red, brown, black and dark.

They are very fertile. Alluvial soil type in the plain is rich in organic matter and good for growing a variety of crops including off season crops. Three main soil types characterizing the area are: lateritic/loamy soils found in lowlying areas. There are also clay soils near raffia palm bushes. Given the hilly nature of the area most of the soils on the mountain slopes have been washed down to the valleys forming a rich fertile zone. Lateritic/loamy soils are used for the making of sun dried bricks. Crops like Irish potatoes; cabbage, carrots and spices are grown in the rich valley soils.

\subsection{A Dense Hydrographic Network}

The hydrological network of Bui Division comprises a dense network of streams flowing in all directions. Many of the flowing streams take their source from the numerous hills in the upper part of Mbiame and Oku Mountain Range. Streams' taking their rise from these areas flow downward to the lowland areas. The major outstanding hydrographic feature in Bui is Lake Oku. Situated on the west end of Bui Division this lake is a potential tourist site. Major rivers in the area include; River Bui, Mbven and other small scale rivers around Mboh-Nso, Lip and Mansaan. The most important stream in the area is the Mairin which flows through Takui, Kishong, Kuintar, Ndzennso and Ngendzen. Ngomrin is an outstanding water fall situated at Kuintar. Other streams worth mentioning are the; Mbi at Nseh with a water fall at Bawong, Nlikpu at Dzeng with a water fall, Liiwon with a water fall and pool. In Ndzennso there is the Nguh and Mingiv; Tatum has the Mbam, Mah-Memfu. Fishing is practised in the Kintsen water fall between 
Mboshah and Mbiim. Major waterfalls are found in forest areas [4].

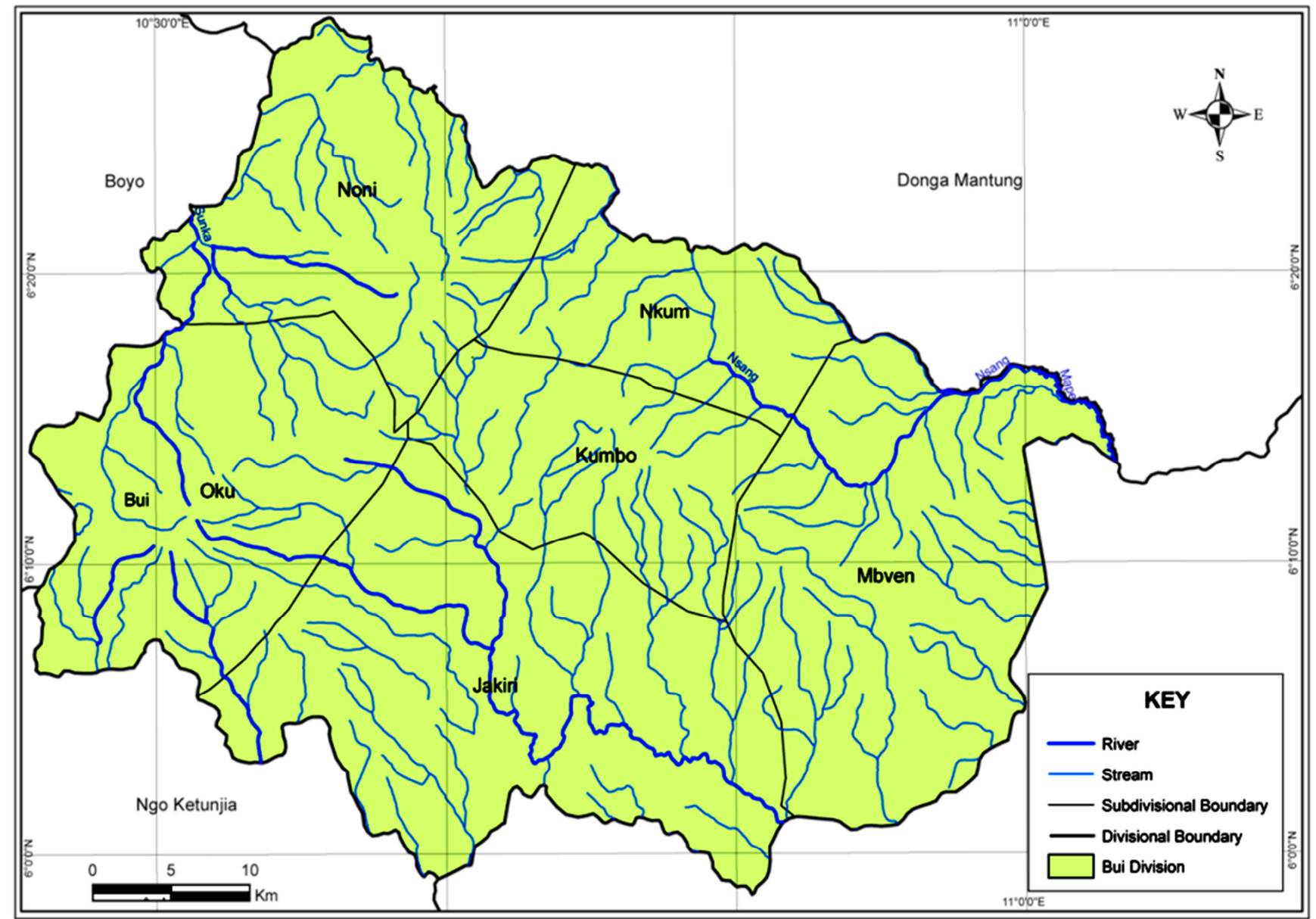

Source: Landsat Image 2015

Figure 2. Hydrographic distribution of Bui Division.

\subsection{Suitable Climatic Background for Crops}

The climate of Bui and its agro ecological zone is of the tropical humid mountain type. This climate has two distinct seasons: the rainy season that lasts from mid March to October, and the dry season from November to mid-March. Figure 1 shows rainfall data collected from 1998-2010 for Bui Division.

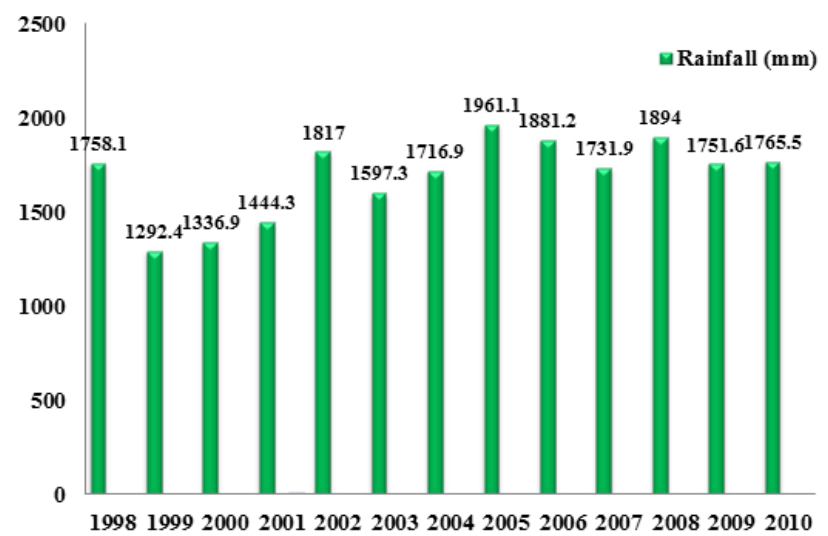

Figure 3. Rainfall for Bui from 1998-2010.
An analysis of figure 3 shows that annual rainfall varies from $1290 \mathrm{~mm}$ in the plains to over $3800 \mathrm{~mm}$ on highland peaks. Plain areas are found in; Mbawnso, Mbam and Mbokam. The highest mountain peak is the Oku Mountain Area (OMA). The largest part of agricultural activity takes place during the rainy season. The division is poorly equipped with irrigation infrastructure. Mean monthly temperatures range from $11^{\circ} \mathrm{C}$ on the highlands to more than $27^{\circ} \mathrm{C}$ in lowlying areas. Tatum is posed with an ecological variation and this has greatly influenced agricultural activities and settlement patterns. In Tatum, the average annual rainfall is about $1862 \mathrm{~mm}$. The dry season runs from October to February. Here nights/days are very cold with average temperatures hardly exceeding $19^{\circ} \mathrm{C}$. Heavy cloud descends from the hills leading to advection fog and during its occurrence visibility is very poor. The rainfall pattern provides suitable conditions for both perennial and annual crops. Rainfall is one of the most important climatic factors influencing agriculture thus determining the potential of the area. Generally, rainfall determines the crops grown, the farming system and the sequence and timing of farming operations. It is the supplier of soil moisture for crops and grassland; farmers depend on rain for arable farming. In 
addition, this climate is very suitable for market gardening activities that are abundant in the division.

\section{Climate Change and Techniques of Local Resilience in Crop Cultivation}

Climate change threatens resources such as water availability for crops, soils fertility, and biodiversity thus broadening the challenge to farming operations. Agriculture at the global, regional and local scale needs to adapt to climate change, so as to maintain or boost crop output. Local farmers spare no efforts at their own level not to be the hardest hit from the negative impacts of climate change. This activity stands out categorical as one of the human endeavors likely to suffer from climate change. Accompanied by higher average temperatures, changes in rainfall patterns and excessive winds, all these multiply threats to sustainable food crop cultivation within the area, thus meticulously needing an adequate resilience means and techniques. Climate change outcomes are complex and require a vigorous approach enhancing an increased resilience and the development of "climate smart" farming operations.

Farmers in Bui Division have particularly demonstrated their ability to adapt and move on systematically with an increased resilience to climate variability despite their biophysical challenges. The indigenes within the area have adopted land and water management practices aimed at reducing soil erosion, biomass transfer, capturing more rainfall, increasing soil organic matter, use of slurry and rotational techniques. Irrigation with the use of locally made pipes is a common practice in dry valleys suitable for the cultivation of vegetables. In far off areas in Bui Division, the use of Indian bamboos, rubber pipes and dug canals are very common thus maintaining output levels. The use of motor pumps is not so common in this area [5].

Their efforts are adapted to strategies needed to restore the productivity of cropland and produce enough food for the population. Vegetables grown in valleys include spices, carrots, tomatoes, pepper and huckkle berry. More than $80 \%$ of these vegetables are destined for the market. The farmers are adaptive to mitigation strategies, thus reducing their vulnerability to suffer huge losses in output. This is glaring with the shift in planting corn, beans and potatoes by more than $90 \%$ of farmers within the division. a proper mitigation to climate change involves the planting of trees, tree planting in degraded lands, reducing deforestation, maintaining natural habitats and improving soil fertility techniques. Above all, increasing skills, knowledge, techniques and practices to cope with suitable farm operations remains a coping means to climate change. Adaptation measures are now inevitable and also imperative to maintain resilience in crop cultivation.

\subsection{Soil Fertility Techniques}

\subsubsection{Short Term Coping Strategies}

Field surveys revealed that $36 \%$ of sampled farmers use domestic waste, crop residue and animal droppings as a short term coping strategy to fertilize the soil and reap benefits of an increased output. The use of domestic waste, slurry, food remains, crop residue and animal dropping remains substantial in maintaining additional yields as a local resilient technique practiced by indigenous farmers in Bui Division. This is systematically based on the use of chemical fertilizers, improved seeds and plant vegetal waste products within a bio-physical setting. The use of chemical fertilizers revealed that $40 \%$ of the populations are actively involved within the area as seen in the figure 2.

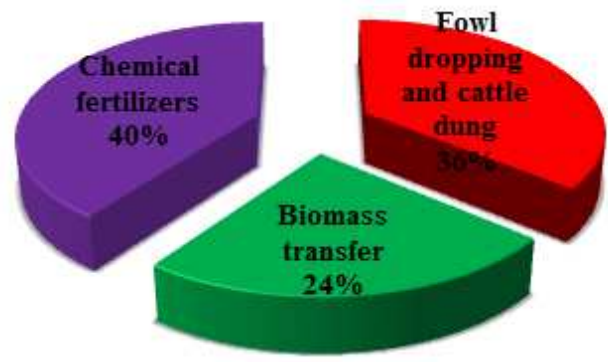

Source: Field survey, 2016

Figure 4. Percentage of farmers adopting short term coping strategies of soil fertility.

From figure 4, biomass transfer to the farms is practiced by $24 \%$ of the population. The use of organic fertilizer sources, domestic waste, crop residue and animal droppings improves soil structure thus assuring resilience in the cultivation of crops such as maize, beans, potatoes, yams and cassava. This approach therefore helps improve the soil's moisture retention capacity as well as favorable conditions for crop growth and harvest. The primary objective of soil conservation is maintenance of fertility assuring increased output. Local techniques used in maintaining soil fertility before planting crops is shown in figure 5 .

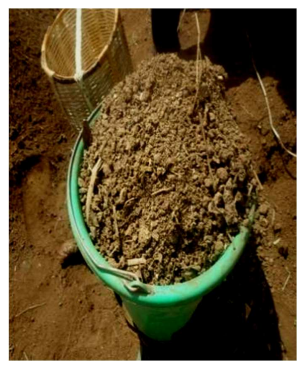

a: Bucket with fowl dropping.

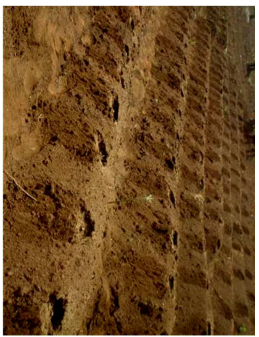

b: Holes dug to be filled with fowl droppings. 


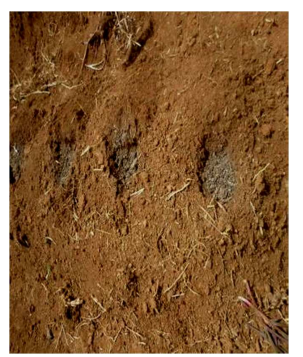

c: Holes filled with fowl dropping. Corn seeds are planted inside the dung in the hole

Source: GodwillTobouah, 04/03/2018

Figure 5. The use of fowl droppings as manure in farms.

From figure 5 and field work findings, farmers in Bui Division use animal droppings as a way of fertilizing their farms. Animal dung is collected and taken to the farms as seen in Figure 5a. Small holes are dug at an equidistance of $0.80 \mathrm{~cm}$ as shown in the Figure 5. The holes are filled with a handful of cattle droppings as shown in Figure 5. This exercise takes place before the first rains from $15^{\text {th }}$ to the $20^{\text {th }}$ of March. After the coming of the rains, maize seeds are sown in the holes and covered with ground. It is practiced on dryferallitic soils. This inorganic fertilizer is also applied on vegetables and spices.

\subsubsection{Chemical Fertilizer Use Pattern}

Chemical elements essential for proper crop development and growth of plants are typically referred to as nutrients. Plant nutrients recognized as being necessary for plant growth has increased over the years thus enlarging prospects and use of inputs according to the nature of the soil and setting In the North West Region and particularly in Bui Division, the use of chemical fertilizers is very common. Farmers depend on fertilizers to boost agricultural production as seen on table 2 .

Table 2. Fertilizer Types used in NWR (\%).

\begin{tabular}{lll}
\hline Fertilizers & $\mathbf{2 0 1 0}$ & $\mathbf{2 0 1 1}$ \\
\hline Chemical fertilizers & $80.8 \%$ & $81.3 \%$ \\
Organic manure & $19.2 \%$ & $18.7 \%$ \\
\hline
\end{tabular}

Source: MINADER-DESA, 2012

From table 2, $80.8 \%$ of North West farmers used chemical fertilizers in 2010. The figures increased in 2011 to $81.3 \%$. As for femure organic, in $2010,19.2 \%$ used this fertilizer. The figures dropped to $18.7 \%$ in 2011 . The main impediment to fertilizer use among smallholder farmers in Bui is its high cost. Chemical fertilizer is expensive. Considering the low purchasing power of local farmers in Bui, buying the needed quantity of fertilizers during the farming season remains a problem. Fertilizer prices have been increasing steadily up to about 18.000 FCFA and even 20.000 FCFA in far off areas like Mbiame, Dzeng, Ngondzen and Nkor [6]. These prices witnessed an increase of more than $90 \%$ over a period of five years. These fertilizer use rates with reference to $85 \%$ native farmers in Bui are seen to be floppy in sustaining soil fertility and crop growth. This is considered one of the main reasons for the propagation of agro forestry innovations in Bui over the last 30 years.

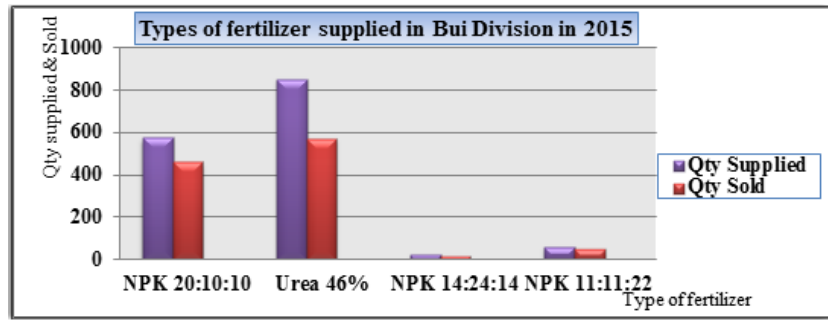

Source: Nso Area Cooperative Union 2015

Figure 6. Types of fertilizers supplied in Bui Division in 2015.

The use of chemical fertilizers is associated with high mean yield increases of major crops cultivated over the years in Bui Division. However, it must be noted that only $88 \%$ of the sampled farming population use chemical fertilizers. Also, only about $66 \%$ of those using fertilizers were able to meet up to $60 \%$ of their fertilizer needs and about $40 \%$ satisfied more than $80 \%$ of their fertilizer needs. Research findings gathered that Urea $46 \%$ was the most widely used fertilizer with 574 bags bought out of the 852 bags supplied. This was followed by NPK 20:10:10 in which 576 bags were supplied with 460 bags sold out. Thirdly used is NPK 11:11:22 in which 62 bags were supplied with 49 bags sold. The supply of NPK 14:24:14 was limited with 27 bags with 19 bags sold. The least used fertilizer was YaraLiva with only 05 bags supplied and 04 bags sold.

\subsection{Biomass Transfer from Kilum Mountain Forest to Farms}

Biomass transfer refers to mulching or green leaf manuring using tree or shrub or leave foliage obtained from forest humus and applied to the cropping fields with the objective of increasing output and maintaining production. Improved fallows, and biomass transfer remains a technique of increasing existing hedges on farm borders and organic nutrients for crops to thrive. Decomposed foliage from the Kilum Mountain and other community forests is spread on farms directly as green manure especially when collected during the dry season, a period considered as a non-cropping. Alternatively in some localities where cow dung is available, litter collected is mixed with animal waste to increase soil fertility and boost output. The practice of biomass transfer or mulching with green leaf compost using foliage of trees and shrubs cut and carried to cropping areas is a traditional practice in many areas within the study area. Gathering and transportation of biomass from forest areas demands much labour and its time consuming. Its application on high value crops such as vegetables with a greater profitability and output positively adds to output. Once biomass is incorporated in the farms, there is no need for fertilizer application until the crop matures, harvested and taken to the markets. As an innovative practice in Oku, about $15 \%$ of farmers carry decomposed manures from the forest to their farms. In terms of payment, Mrs, Ngala Vivian spends close 
to 15.000 FCFA to get 8 bags of decomposed manure from the forest to her farm in Ngveinkei 11. A glaring example of this practice is found on farms closer to the forest in Upland Oku [7].

\section{Long Term Strategies of Maintaining Fertile Soils}

A panoramic outlook of far off localities in Mbiame, Oku, Tatum, Mbinon, Kovifem, Nkar, Jakiri, Vekovi and Djottin is marked by tree cover countryside. Forest soils, normally rated unsuitable for crops, can be improved by growing leguminous tree species. Besides the medicinal value of tree roots, leaves, barks, fruits, wood carving and food, trees are considered by more than $82 \%$ of the indigenes to positively act in soil fertility improvement on the long term.

Table 3. Percentage of farmers adopting techniques of soil fertility.

\begin{tabular}{lll}
\hline Farming prcatices & $\begin{array}{l}\text { Number of } \\
\text { respondents }\end{array}$ & $\begin{array}{l}\text { Percentage of } \\
\text { respondents }\end{array}$ \\
\hline Biomass transfer from the forest & 16 & 08.69 \\
Use of fertilizer & 60 & 32.60 \\
Use of slurry from piggery & 06 & 03.26 \\
Soil fertility enrichment trees & 20 & 10.86 \\
Reduction in slash and burn methods & 14 & 07.60 \\
Fowl dropping, dung and compost & 30 & 16.30 \\
Use of HYV seeds & 20 & 10.86 \\
Improved agro forestry practices & 14 & 07.60 \\
Others & 04 & 02.17 \\
Total & 184 & 100 \\
\hline
\end{tabular}

Source: Field survey, 2016, 2017 and 2018

Field findings strongly proved that $32.60 \%$ of a total of 100 percent use chemical fertilizers. This accounts for close to $60 \%$ of the number of respondents. Despite this, long term coping strategies of fertilizing the soil are progressively being put in place. In this light, $16.30 \%$ of respondents apply compost manure, fowl dropping and cattle dung 10.86\% plant soil fertility enrichment trees, $08.69 \%$ are involved in biomass transfer from the forest to their farms while $07.60 \%$ practice improved agro forestry. Soil fertility on farm findings, assert that farmers in Mbiame, Oku, Tatum, Mbinon, Kovifem, Nkar, Jakiri, Vekovi and Djottin plant soil fertility improvement trees such as Tephrosiavogeli, Scheffleraabyssinica, Crassocephalummannili, Leucanea and Gliricardipossess organic manure to improve on the fertility of their soils and the building up of soil organic matter and recycling nutrients on farms.

The vital place accorded to trees by the above communities in Bui is an indication of their belief on the positive role they play on soil fertility. With The planting and maintenance of Tephrosiavogeli, Scheffleraabyssinica, Crassocephalummannili, Leucanea and Gliricardi, soil nutrient balance sheet is maintained in farms. Studies disclose that more than $86 \%$ of these trees hold nitrogen and potassium for plants from their fallen decomposed leaves. Tree and shrub species that are suitable for biomass transfer are the same as those for improved fallows and include
Gliricidiasepium, Leucaenaspp, Sesbaniasesban, and Tephrosiavogelii. Among these species Gliricidiasepium is said to be the best due to its coppicing ability as seen in the following trees.

Table 4. Percentage of Soil Fertility Trees Planted in Kumbo and Oku.

\begin{tabular}{llll}
\hline \multirow{2}{*}{ Tree specie (Latin Name) } & \multicolumn{2}{l}{ Specie Name in Dialect } & \% \\
\cline { 2 - 4 } & Lamnso & Oku & \\
\hline Tephrosiavogeli & Korin & Koolein & 45 \\
Leucanea & Kichii & Djia & 30 \\
Scheffleraabyssinica & Shaai & Kibongolingos & 15 \\
Crassocephalummannili & Kibuchuum & Ngangang & 06 \\
Gliricardi & Ebluun & Eyis & 04 \\
Total & & & 100 \\
\hline
\end{tabular}

Source: Field survey, July 2019

Fieldwork findings affirm that $74 \%$ of respondents clearly agreed that some specie of trees found on their farms maintain soil fertility. A good number of these trees heterogeneously spread such as Tephrosiavogeli, Scheffleraabyssinica, Crassocephalummannili, Leucanea and Gliricardi are found on farms. The leaves and roots of these trees are suitable for maintaining soil fertility and softening their farms in the long run. Generally, seeds from these tree species are distributed by wind during the dry season not putting aside nursed species ofTephrosiavogeli, Scheffleraabyssinica, Crassocephalummannili and Leucaneausing local techniques. Findings from the study revealed that $95 \%$ of farmers agreed that more than $75 \%$ species of trees found on their farms serve in maintaining soil fertility. The leaves and roots of these trees are suitable for maintaining soil fertility. Farmers' perceptions of trees to soften farms equally vary a lot within the study area. About $45 \%$ of farmers interviewed believed that continuous cultivation of their farms was a way of softening the farms while $55 \%$ considered some species of trees as very good trees for softening farms. These trees includeTephrosiavogeli, ScheffleraabyssinicaandCrassocephalummannili. Other trees such as Leucanea and Gliricardi play the vital role of checking wind erosion, building up soil organic matter and recycling nutrients on farms [8].

\section{Local Mitigation Strategies to Maintain Crop Output}

The success and continues struggle of alleviation strategies is contributing to the survival of crop cultivation and striking a fair balance between efforts and output in the agricultural sector and the sustainable use and management of resources. The indigenes have developed local strategies to cultivate, conserve and harvest crops within the area thus maintain the equilibrium in this domain. There is awareness in challenges, abilities, skills, knowledge and practices of the farmers to adapt to the local changing situations of the area, thus fostering their resilience in crop cultivation. Farmers are demonstrating varieties of adaptation and mitigation strategies across many localities in Bui Division. The use of traditional knowledge, 
innovations and practices within the area calls for an adherence in their resilient efforts. Modification of traditional knowledge is blending with modern technologies thus maintaining their challenges and stakes.

To recognize both the vulnerability and the contributions of the indigenes in designing culturally appropriate adaptation and mitigation development of their communities. Within the context of this study, the introduction of local techniques is based on the cultural background and the use of local materials to bring innovative solutions and maintain their strong hold in this domain.

\section{Relatively Highland Landscape of Bui}

Situated in the western highland region of Cameroon, the relief of Bui Division is about 55\% highland dominated. The terrain consists mainly of highlands ranging from $1400 \mathrm{~m}$ and above sea level on the west end precisely the Oku Mountain Area and its surroundings to parts of Kumbo extending to Tatum. Approximately, these areas occupy about $40 \%$ of the total land surface of the division as seen in figure 7 .

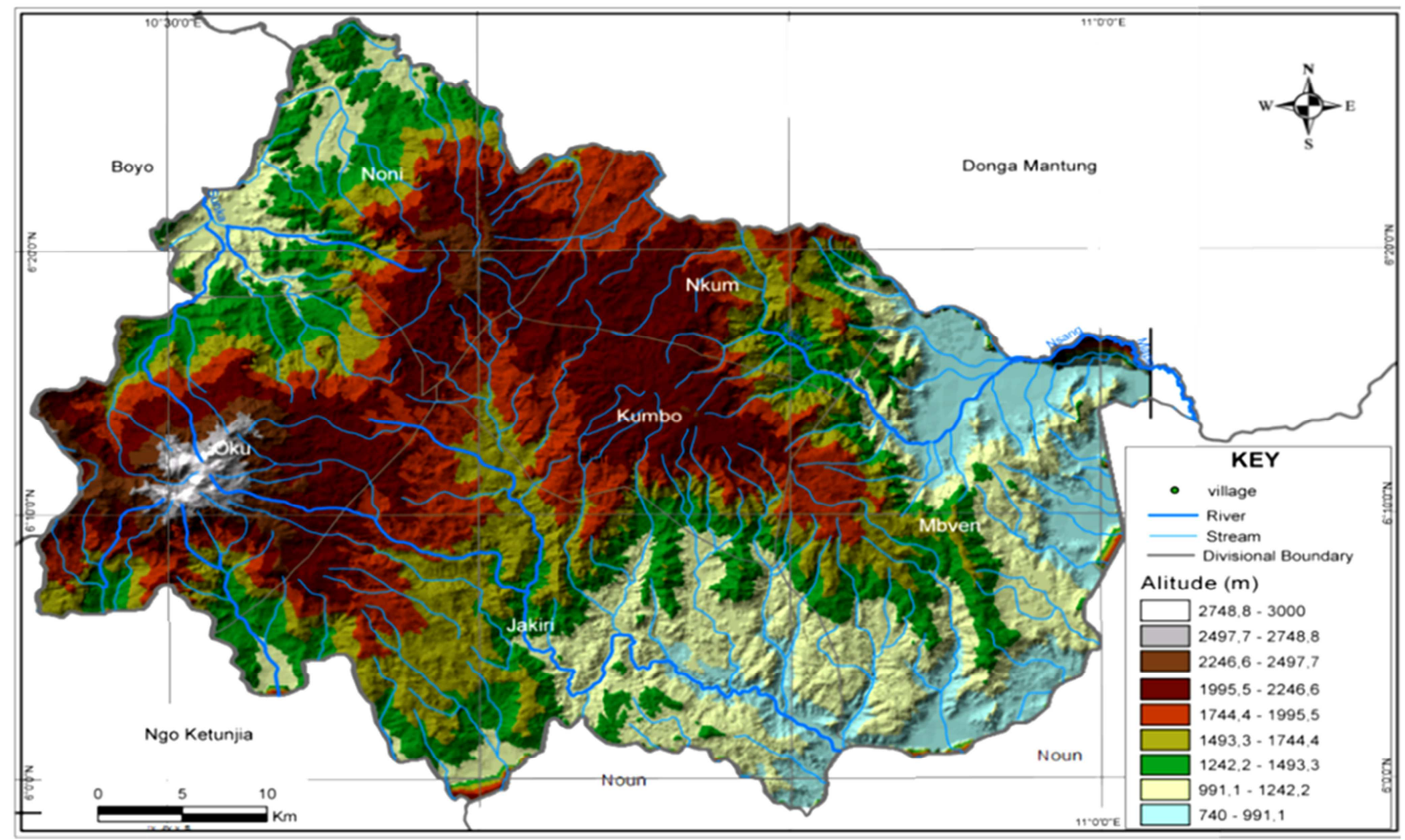

Source: Land sat image, 2018

Figure 7. Relief map of Bui Division.

A closer reading of the map shows that pockets of plains ranging from $740-991 \mathrm{~m}$ above sea level are situated at the south east and parts of the north east areas of Bui. These plains are surrounded by a relatively higher zone ranging from $992 \mathrm{~m}$ to about $1495 \mathrm{~m}$ above sea level. These areas are promising for the development of agro forestry. As a matter of fact, the area is endowed with different types of vegetation. The landscape is mainly grass with fringes of forest along the gentle slopes and narrow valleys. In addition, Fulani's occupy the grassland areas of the mountain slopes for grazing. Extensive grass cover is found on hills in carpet like shape, which gives a touch of beauty to the landscape [9].. However, the landscape and vegetation types have greatly degenerated over the years. This has been as a result of constant bush fires set by grazers and sometimes by farmers who practice slash and burn. Some of the forest is being exploited for timber and clearing to extend farm lands.
The area is also very rich in planted eucalyptus trees. Biogas systems produce biogas slurry (organic matter) which is a byproduct of biogas production is a high quality fertilizer which does not smell and easily applied on the ridges. This fertilizer can be spread directly on the crops at any time of the year and in all seasons. Slurry used in the farm contributes to production and reduces dependency on chemical fertilizer thus increasing savings and improvements in standards of living [10].

In Bui Division, Biogas is produced in the Strategic Humanitarian Services (SHUMAS) Integrated Organic Farm (BIOFARM) Centre at Kingomen and in Mbiame. The BIOFARM Centre biogas system is a floating drum system measuring $25 \mathrm{~m}^{3}$. The system provides $18 \mathrm{~m}^{3}$ of biogas per day to prepare food for students, treat effectively animal waste for use as biofertilizer; produce earthworms for table birds and increase algae growth in fish ponds; use clean 
energy in the place of firewood for food preparation and in the long run produce biopesticide from digestate to fight plant diseases.

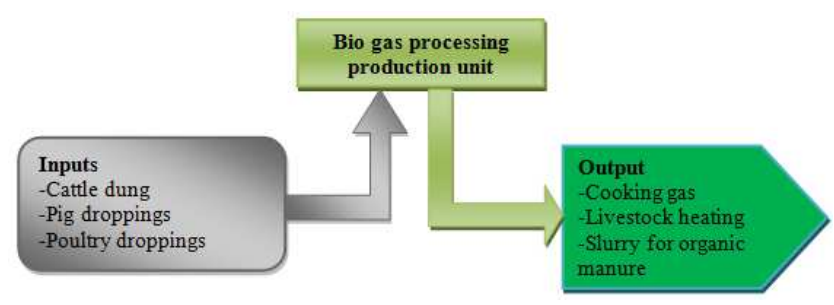

Source: Author's conception

Figure 8. A simplified biogas innovation unit.

The liquid is collected in a biogas digestate. The digestate in semi liquid form is collected from the biogas system outlet chamber with spades in the dry season and allowed to dry by placing it on a specially prepared disgetate space. This digestate takes 10 days to dry after which it is crushed and kept for use [11]. This digestate is collected for about 40 days to get the right quantity needed to be applied on farms. Before application it is thoroughly mixed and spread on prepared beds uniformly. This makes the $\mathrm{pH}$ of the soil basic, rich in nitrogen, phosphorus and potassium thus suitable for the cultivation of crops and vegetables as proven in many localities within the study area.

\section{Family Agriculture and as a Way of Boosting Resilience}

Even though men are the family heads, when it comes to food crops and food security women are at the frontlines to maintain their motherly role. Gender representation at the level of family agriculture as a way of boosting resilience projects as a positive and majority of the females workers actively involved in this activity. Typically it is the women who have the responsibility of feeding families and growing food crops for home consumption thus guaranteeing resilience. Women are the guardians of household food security. Despite this, women tend to have limited access to resources that could improve the quality and quantity of the food they produce. Innovation in family agriculture and their resilience step is essential for strengthening the productivity, competitiveness and sustainability of the crop sector. the men highly involved in other sectors of agriculture like the cultivation of cash crops and the rest into other activities. Strengthening family agriculture, contributes globally to producing the majority of the food consumed in communities within Bui Division [12]. These producers are part of the solution to the food insecurity problems thus holding firm in maintaining farmer resilience and boosting stakes today. Family agriculture is supported by Durkheim as a mechanical solidarity where every member of the society assist the other in times of joy and difficulties. Many small farmers are women and youth, who toil on their farms every day, bring their produce to the markets, and keep themselves informed about climate conditions, product prices, and technologies giving hope to this activity. Resilience capacity to innovation enables farmers, communities and societies to cope with change and prosper by effectively responding to new opportunities and outcomes in the domain. Family farming accounts for more than $98 \%$ of the total number of farms in Bui Division. Innovations on family agriculture must be aligned with the manner of obtaining and optimizing land. Resilience is also manifested in the fact that family agriculture has been coined and connected into cultures as seen in the days allocated for farm work, traditional Sundays commonly called country Sundays has been put in place. On these no farmer is authorized to work on the farm. Activities on this day involve attending quarter meetings, traditional ceremonies, and visiting family members and friends. Culturally, family agriculture is deeply reflected in the production of artifacts such as baskets, traditional outfits and other related objects [13].

Table 51. National Percentages of Surface Areas Destined for Cultivating the Following Crops (\%.).

\begin{tabular}{lllll}
\hline Crop & $\mathbf{2 0 0 8}$ & $\mathbf{2 0 0 9}$ & $\mathbf{2 0 1 0}$ & $\mathbf{2 0 1 1}$ \\
\hline Maize & 35.65 & 38.03 & 36.49 & 36.12 \\
Potatoes & 02.76 & 02.78 & 02.61 & 02.49 \\
Cassava & 46.96 & 47.77 & 47.58 & 48.55 \\
Yams & 07.53 & 07.68 & 07.87 & 07.77 \\
\hline
\end{tabular}

Source: MINADER-DESA, 2011.

Factually table 5 demonstrates that the surface area destined for maize cultivation increased in 2009 to $38.03 \%$ and dropped 36.49 in 2010 and 36.12 in 2011. The area under potatoe and yam cultivation is not worth mentioning in terms of percentage change. At the North West Regional level, cultivation surface areas in terms of hectares witnessed a steady increase in yams and cassava from 2008-2011 as confirmed in table 6 .

Table 6. Cultivated Surface Areas (hectares) within the NWR of the Following Crops.

\begin{tabular}{lllll}
\hline & $\mathbf{2 0 0 8}$ & $\mathbf{2 0 0 9}$ & $\mathbf{2 0 1 0}$ & $\mathbf{2 0 1 1}$ \\
\hline Maize & - & 76878 & 80740 & 70809 \\
Beans & - & 92603 & 113269 & 115184 \\
Yams & 4029 & 5201 & 6491 & 6575 \\
Cassava & 6045 & 10758 & 13768 & 14264 \\
Potatoes & 5490 & 4212 & 4007 & 4103 \\
\hline
\end{tabular}

Source: Statistical year book 2013, Pg. 249.

\subsection{Local Agricultural Production Interface}

The fluctuation registered from the major crop sectors in the entire region as a whole remains a major contributing factor in eradicating poverty and extreme hunger. An assemblage of the North West Regional production statistics from 2004-2011 is a testimony to the rise and fall of total production of crops as illustrated in figure 8 . 


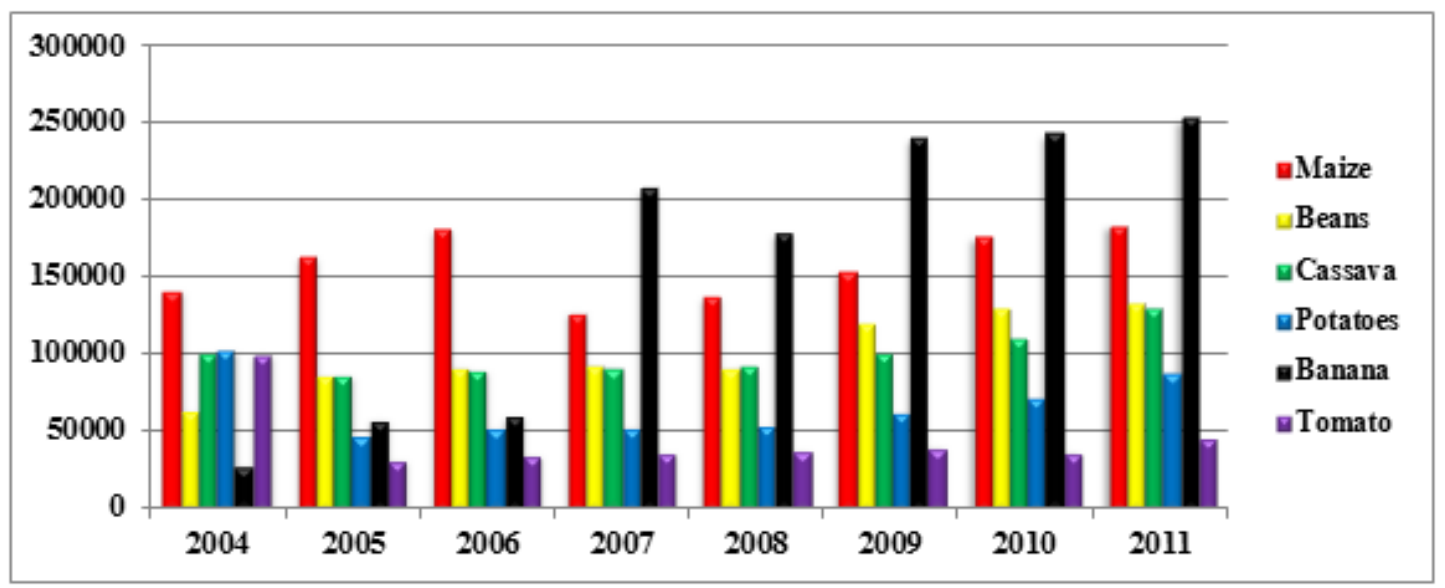

Source: Statistical year book 2013, Pg. 249

Figure 9. Output of selected crops in the NWR from 2004-2011 in Tons.

A look at figure 9 reveals that maize, beans, cassava, banana and tomato output over the years witnessed a fluctuating production within the entire region. The figure reveals that innovations in the different crops are gradually gaining ground.

\subsection{Intensive Outlookin Crop Cultivation}

Table 7. Traditional Versus Modern Farming

\begin{tabular}{lll}
\hline Characteristics & Traditional Farming & Modern Farming \\
\hline Farm preparation techniques & Slash and burn, ankara & Slash and mulch \\
Tools used in cultivation & Sticks, cutlass, hoes, diggers & Mechanize, cutlass, Tractors, sprayers etc \\
Type of practice & Rotational bush fallo, shifting cultivation & Intensive cultivation onfixed land \\
Types of Seeds planted & Local seeds & Higher Yielding Variety (HYV) seeds, vegetative propagation. \\
Use of nursery & Absence of nursery groups & Specialized groups of seed nursery \\
Sowing interval & Irregular space planting & Regular space planting \\
Manuring techniques & Organic manure & Compost, chemical fertilizers \\
Weeding methods & Use of hands and hoes to remove weeds & Use of chemicals to kill weeds \\
Farm maintenance & Local techniques & Modern techniques \\
Water supply & Rainfed agriculture & Rainfed, watering using cans, buckets, sprinklers, irrigation \\
Conservation technique & Not treated before conserve & Treated before conserve \\
Type of labour & Unskilled labour & Semi skilled and skilled labour \\
Output time & Late maturing crops & Early maturing crops \\
\hline
\end{tabular}

Source: Field survey, March, 2016

From table 7, there has been a great improvement in terms of qualitative cultivation. Since almost all rural households in Bui depend directly or indirectly on agriculture, and given the large contribution of this sector to the overall economy, it is obvious that agriculture remains a key component of growth and rural development in Cameroon in general and Bui in particular. Yet, while traditional subsistence agriculture is generally an important component of rural development in Bui as confirmed by more than $95 \%$ of farmers, its ability to generate growth and reduce poverty depends on the nature of its intensification. Intensification in terms of inputs and processes of traditional agriculture is important not only for generating growth but also for reducing poverty and inequality within the rural milieu of Bui. Field investigations equally revealed that $72 \%$ of farmers incorporate modern methods of farming. Only $28 \%$ are conservative as seen in figure 10 .
Generally, more than $90 \%$ of rural farmers within the study area practice traditional subsistence agriculture even though given a new face lift. The main objective of the households in the rural areas of Bui is to maximize the harvest from their traditional daily practice. Table 7 compares traditional and qualitative modern farming as practiced in Bui Division. Early maturing crops 
modernization has a significant impact on poverty reduction. Agricultural innovations have a very strong effect on reducing poverty and enhancing growth. This growth is due in part to its generation of both agricultural and non agricultural activities creating local employment. A key relationship between growth in agriculture and poverty is that it directly generates demand for rural labor. Subsistence agricultural growth benefits both the rural and urban consumers alike by driving down food prices. Farm activities are diagnostic approaches that guide the analysis of the complex agricultural innovations of the natives of Bui. This focuses on the integrated analysis of different farming techniques used to overcome problems that are largely biophysical, technological, socio cultural, economic and institutional. Innovation capacity in this agricultural system is studied by analyzing the rate of adoptions.

Their introduction has helped to boost agricultural production in the study area. More than $85 \%$ of farmers in Bui from field work observations were unanimous on their preference of this category of seeds. Indeed these farmers are mostly of the younger generation and still energetic. Research findings indicate that their ages range from $20-55$ years. They are those actively involved in agriculture. The remaining $20 \%$ of farmers are conservative. Age wise this proportion is dominated by the elderly class still practising farming. This category of persons is adamant to change. The elderly class pays less attention to these innovations and considers it a rudimentary way of changing the status quo. Nonetheless, the prevalence of HYVs seeds nowadays dominates the entire landscape of Bui Division. These seed species include prevailing food crop types cultivated on the entire landscape of Bui Division. Figure 11 is an example of HYV maize seeds planted in Mbah.

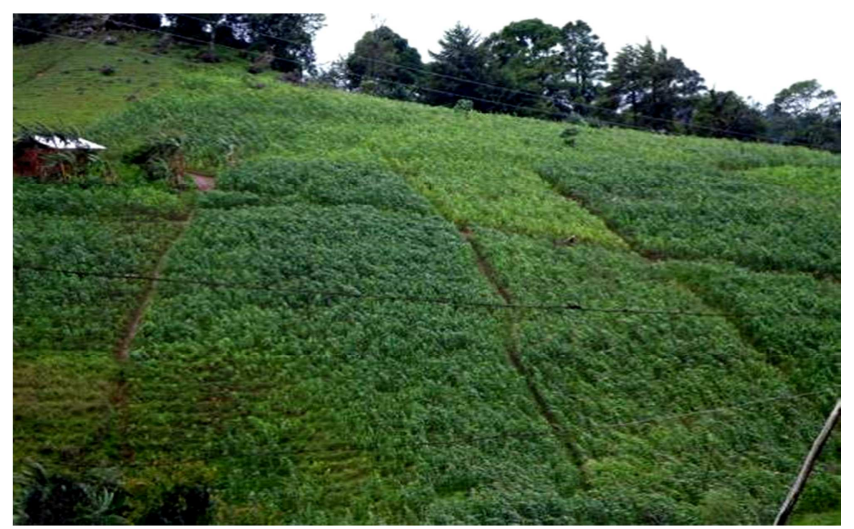

Figure 11. Extensive farmlands of High Yielding Variety maize. Generally, this farmland produces quality maize. Source: Tobouah, 20/08/2019.

From figure 11, two species of maize are cultivated by local farmers in Bui. This includes white and yellow corn. Seeds planted are of different types such as: Cameroon Maize Selection (CMS), the Kasai (CHC 201), Coca SR and the ATP (CHC 202). Field findings revealed that $85 \%$ of farmers in Bui prefer the white corn specie to the yellow. The simple reason is that fufu prepared from white corn tastes better than that from yellow corn. Other HYV seeds species include;
NUA -99, B.G.G, DOR -701, P.N.N, NUV-109-2, and MIDENO spotted, Red, White. Potatoe species include; Cipira, Tupira, Nicholas, Solanum. Innovation is at the basis of economic development in this dimension. It is instrumental in modernizing the rural life styles of farmers in Bui Division from their harvests [14].

Prices of maize seeds range between 850 FCFA and 1000 FCFA depending on the kind and size of the package. The development of better input markets and delivery systems for new technology, extension services and information directly translate into improvements in food production in Bui Division. A reliable supply of these inputs guarantees food security and the improvement of livelihoods. Additionally, reliable commodity markets for farmers' produce in the local markets if improved upon will make the impact of these innovations even greater.

As a matter of fact, good quality seeds as an input into small scale farming systems have proven to be instrumental in yield improvements. In 2012 the Support Program for Production and Distribution of Seeds and Planting Materials (PAPDIMAV) was introduced by the Government of Cameroon to enhance farmers' access to better quality seeds. Together with the state institution in charge of agricultural research (the Institute for Research in Agriculture and Development), the government trains and provides materials meant to stimulate local interest in producing and selling high-quality seeds at affordable prices to smallholder farmers. Such seed production at a local level does not only provides incomes to households engaged in seed production, but also encourage the use of higher quality seeds for food production among food crop farmers [15]. Table 8 shows the percentage of households using HYV seeds in Cameroon.

Table 8. Households Using HYV Seeds in Cameroon (\%).

\begin{tabular}{llll}
\hline Food crop & $\mathbf{2 0 0 9}$ & $\mathbf{2 0 1 0}$ & $\mathbf{2 0 1 1}$ \\
\hline Maize & 42.6 & 46.2 & 52.8 \\
Yams tubers & 10.8 & 09 & 10.9 \\
Macabo-taro & 3.8 & 03.2 & 05.3 \\
Cassava & 18.8 & 16.8 & 19.1 \\
Potatoes & 23 & 25.4 & 24.1 \\
Ground Nuts & 03.3 & 02.9 & 03.1 \\
Beans & 07.6 & 11.7 & 06.2 \\
Soja & 09.2 & 22.1 & 23.8 \\
Banana & 06.7 & 11.2 & 11.5 \\
Tomatoes & 68.2 & 65.3 & 69.3 \\
Plantains & 07.4 & 08 & 07.8 \\
\hline
\end{tabular}

Source: MINADER-DESA 2012

From table 8 , it is clear that the use of HYV seeds is steadily gaining ground nationwide. The trend is generally increasing in all the crops cultivated. Generally speaking, the challenge is not only in developing HYV seeds but also in their dissemination too far off farmers in Bui Division. Rather, varieties should respond to local socio-economic and cultural demands such as taste and storage potentials. To be sustainable, varieties also have to respond to growing environmental challenges in this area such as longer dry 
spells, nutrient use efficiency, demand for crops and stability of yields. Above all, these species of seeds are of a higher quality. Traditionally, within Bui Division, there has been a source of genetic diversity of crops important for human consumption, as in the case of maize, beans, Irish potatoes and sweet potatoes. Many crops and varieties grown are now being widely planted. Relatively these seeds can provide a sustainable long term solution for a viable seed sector in Cameroon, given the present level of socio-economic and technological development of agriculture [16].

\subsection{Traditional Versus HYV Seeds in Bui}

Farmers depend considerably on the quality of seeds planted for viable crops and a good harvest. generally believed to have originated from Central America, Maize (zea mays) was first introduced in Nso during the period of early migration into the territory. The first species of corn ("Ngwasnang - Nso", literally, Nso-corn) was probably from the Tikar country, Bamkim. The local variety of corn that was grown hardly exceeded 2 meters, it produced very small cobs, and its size could equally be associated with poor methods of cultivation. Even though these seeds produce less than the HYV species, they still remain the most preferred by the elderly class. The traditional method of saving some from the previous harvest as seeds for the next year are planting has gone on for several generations in the study area. Through such seed savings, smallholder farmers save in order to conserve many of the genetic materials used for several generations. Some of these genetic materials have survived different environmental challenges that the division has faced during this time. Research into seeds with higher production potential, pest resistance, drought tolerance and other beneficial traits for the region is bringing about improvements in some of the original seed stocks. Table 9 generally compares traditional seeds and the HYV species.

Table 9. Traditional Versus HYV Seeds planted in Bui.

\begin{tabular}{lll}
\hline Characteristics & Traditionalseeds & Higher Yielding Variety (HYV) seeds \\
\hline Resistance & Resistant & Less resistant \\
Storage duration & Can be stored for long & Cannot be stored for long \\
Cost & Moderate & Expensive \\
Output & Less output & More output \\
Growth period & Longer period & Shorter period \\
Taste & Good taste & Less tasteful \\
Grain size & Smaller grain size & Larger grain size \\
Labour demands & Demands much labour & Less labour input \\
\hline
\end{tabular}

Source: Field survey, June 2018

Even though preference today is tilting in favour of HYV, local seeds present the best qualities. Local seeds are considered to be of high quality and original than the HYV type. The main handicap of this specie is limited quantity.

\subsection{Wide Spectrum of Homologated Herbicides Used for Maize}

Research has greatly advanced in the domain of herbicides used for maize. Within our study area only $15 \%$ of farmers use maize herbicides. From the wide range of the homologated insecticides, the most commonly used by these farmers are; Camix 500 SE, Atoll, Eagrowmais, and Herbimais. Table 10 is a list of homologated herbicides used in Cameroon.

Table 10. Homologated Herbicides Used for Maize.

\begin{tabular}{ll}
\hline Name & Active Substance \\
\hline Atoll & Isoxaflutole $37.5 \mathrm{~g} / 1+$ Atrazine $500 \mathrm{~g} / 1$ \\
Callitraz 90WG & Altrazine $900 \mathrm{~g} / \mathrm{kg}$ \\
Camix 500 SE & Mesotrione $8.83 \mathrm{~g} / 1+\mathrm{S}-$ Metolachlore $416.7 \mathrm{~g} / 1$ \\
Eagrowmais & Nicosulfurone $40 \mathrm{~g} / 1$ \\
Herbagran & Bentazone $480 \mathrm{~g} / 1$ \\
Herbimais & Altrazine $750 \mathrm{~g} / \mathrm{l}+\mathrm{Nicosulfuron} 40 \mathrm{~g} / 1$ \\
Herbimais Super & Dicamba $240 \mathrm{~g} / 1+$ Nicosulfuron $40 \mathrm{~g} / 1$ \\
Lumax 537.5 SE & Mesotrione $3.75 \%+$ Metolachlore $37.5 \%$ \\
Maia 75WG & Nicosulfuron $750 \mathrm{~g} / \mathrm{kg}$ \\
Maia Super & Nicosulfuron $60 \mathrm{~g} / \mathrm{kg}$ \\
\hline
\end{tabular}

\begin{tabular}{ll}
\hline Name & Active Substance \\
\hline Nicomais 40SC & Nicosulfuron $40 \mathrm{~g} / \mathrm{kg}$ \\
Pendistar 400 EC & Pendimethaline $400 \mathrm{~g} / 1$ \\
Plantomais 40SC & Nicosulfuron $40 \mathrm{~g} / 1$ \\
Primextra Gold 720 SC & Atrazine $320 \mathrm{~g} / 1+$ Metolachiore $400 / \mathrm{g} / 1$ \\
Sinomais 79WG & Altrazine $750 \mathrm{~g} / 1+$ Nicosulfuron $40 \mathrm{~g} / 1$ \\
Winner Gold 400 SC & Prometryne $20 \%$ + Oxyfluofen $30 \mathrm{~g} / 1$ \\
\hline
\end{tabular}

Source: Liste des Pesticides Homologues au Cameroun: 31 Juillet 2013, 40P.

From table 10 all the above herbicides are used in Bui Division. These herbicides are found in farmers' stores and at co-operative societies. About $85 \%$ of these herbicides are supplied by the Kumbo Coffee Co-operative Union LTD. From here, the different Sub-Divisional capitals of Jakiri, Nkor, Mbiame, Oku and Tatum receive their supplies. However, other farm inputs besides herbicides are supplied by the Kumbo Coffee Cooperative Union LTD.

\subsection{New Beans Species Introduced by IRAD Foumbot}

Discovered by IRAD Foumbot in 2012, these new beans species was presented to the Minister of Scientific Research and Innovation, MadaleineTchuinte on the $10^{\text {th }}$ March 2015 at the IRAD centre in Foumbot. This centre is one of the five operational research centers in the highlands of the West with an antenna in Bangangte. These centers carry out research in maize, cassava, plantains, banana, ground nuts, soya beans and perennial coffee etc. These bean species include the 
following in table 11 .

Table 11. Varieties of New Beans Species Introduced by IRAD Foumbot.

\begin{tabular}{|c|c|c|c|c|c|c|c|}
\hline \multirow{2}{*}{ Specie } & \multirow{2}{*}{ Adapted zones } & \multirow{2}{*}{$\begin{array}{l}\text { Mature } \\
\text { period }\end{array}$} & \multirow{2}{*}{$\begin{array}{l}\text { Vulnerable \& } \\
\text { resistance }\end{array}$} & \multicolumn{2}{|c|}{ Planting period } & \multirow{2}{*}{$\begin{array}{l}\text { Quantity (tons/ha per } \\
\text { year }\end{array}$} & \multirow{2}{*}{ Qualities } \\
\hline & & & & $1^{\text {st }}$ & $2^{\text {nd }}$ & & \\
\hline NUA - 99 & $\begin{array}{l}\text { Humid low } \\
\text { altitude }\end{array}$ & 70-75 days & Highly resistant & $15 / 09$ & $15 / 03-15 / 04$ & About $1.5 \& 2.5$ tons & $\begin{array}{l}\text {-Cooks fast } \\
\text {-Good taste } \\
\text {-High protein content }\end{array}$ \\
\hline B.G.G & Average altitude & 70 days & $\begin{array}{l}\text { Vulnerable to } \\
\text { insects, resistant }\end{array}$ & $15 / 09$ & $15 / 03-15 / 04$ & About $1.2 \& 2$ tons & $\begin{array}{l}\text {-Cooks fast } \\
\text {-Good taste } \\
\text {-Rain tolerance }\end{array}$ \\
\hline DOR -701 & $\begin{array}{l}\text { High, average } \\
\text { and low altitude }\end{array}$ & 80-90 days & $\begin{array}{l}\text { Resistant to } \\
\text { attack }\end{array}$ & $15 / 09$ & $15 / 03-15 / 04$ & About $2 \& 3$ tons & $\begin{array}{l}\text {-Cooks fast } \\
\text {-Good taste } \\
\text {-Rain-Tolerance } \\
\text {-Adaptation to acid soils }\end{array}$ \\
\hline P.N.N & $\begin{array}{l}\text { Average and } \\
\text { low altitude }\end{array}$ & 80-90 days & $\begin{array}{l}\text { Vulnerable to } \\
\text { insects }\end{array}$ & $15 / 09$ & $15 / 03-15 / 04$ & About $1.2 \& 2.5$ tons & $\begin{array}{l}\text {-Cooks fast } \\
\text {-Good taste }\end{array}$ \\
\hline NUV-109-2 & $\begin{array}{l}\text { High, and low } \\
\text { altitude }\end{array}$ & $90-110$ days & Rain resistant & $15 / 09$ & $15 / 03-15 / 04$ & About $2 \& 3$ tons & $\begin{array}{l}\text {-Cooks fast } \\
\text {-Good taste }\end{array}$ \\
\hline NUV-6 & $\begin{array}{l}\text { Mid, high and } \\
\text { low altitude }\end{array}$ & $90-110$ days & Rain resistant & $15 / 09$ & $15 / 03-15 / 04$ & $2 \& 3$ tons & $\begin{array}{l}\text {-Cooks fast-Good taste } \\
\text {-Rain tolerance } \\
\text {-Adaptation to acid soils }\end{array}$ \\
\hline $\begin{array}{l}\text { GUZANG } \\
\text { LOCAL }\end{array}$ & $\begin{array}{l}\text { Mid, high and } \\
\text { low altitude }\end{array}$ & $80-90$ days & $\begin{array}{l}\text { Resistant to } \\
\text { attack }\end{array}$ & $15 / 09$ & $15 / 03-15 / 04$ & $1.5-2$ tons & $\begin{array}{l}\text {-Cooks fast-Good taste } \\
\text {-Rain tolerance } \\
\text {-Adaptation to acid soils }\end{array}$ \\
\hline
\end{tabular}

Source: Paysan Elite, $\mathrm{N}^{\circ} 036$ of April 2015, Pg 8 and Science etdeveloppement $\mathrm{N}^{\circ} 011$ - Mai 2014 Pg. 32/33

Generally, from table 11 presented, the Western Highland Region presents an ecologically suitable background for the growth of these new bean species.

\subsection{Solanum Potato Seed Multiplication Farms}

Potato is grown in Cameroon between 900 and 3000 meters above sea level [17]. About $95 \%$ of potato farms are located between 1000 and $2000 \mathrm{~m}$. It is grown on a total land surface of about 72.103 hectares in the country in six regions. The North West and West Regions are the highest producing areas of the country, accounting for more than $80 \%$ of the national production. Two main cropping season starts from March July and the late season which runs from August to November. The most cultivated potato variety is CIPIRA (53-66\%) which is an IRAD variety. It is followed by the local varieties (17\%) and Spunta (10-21\%). Both Cipira and Tupira have been widely adopted by potato farmers in Bui Division. According to informants in Mbockenghas, Simonkoh and Tangkiy or Fonmboh, adjacent the Ngongbaa Forest, the CIPIRA species of Irish potato was taken by Mr. Musa TatahMbinkar from Santa to Bui Division in the early 1980s [18]. Figure 12 shows a potato seed multiplication farm in Oku.

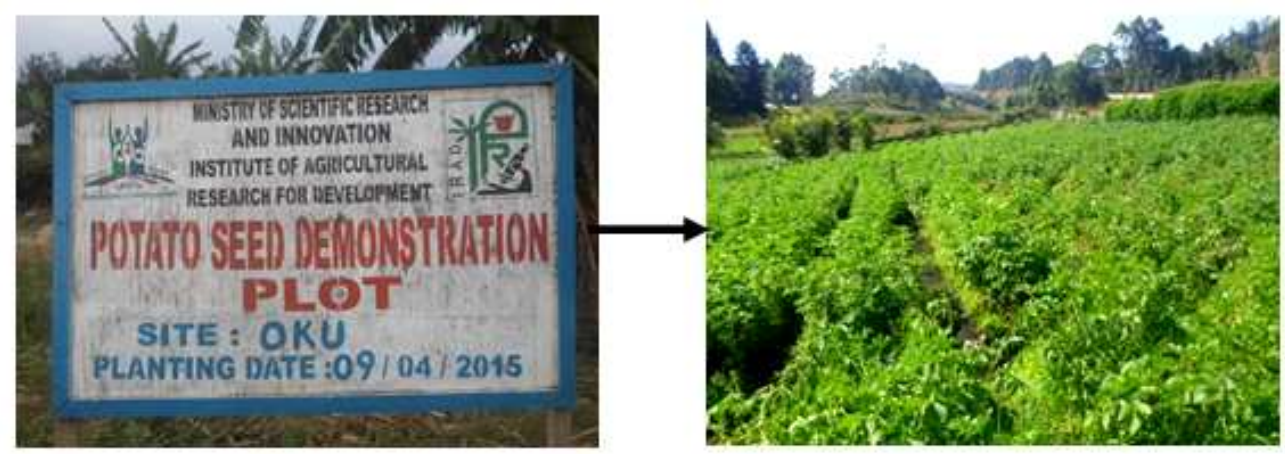

Source: Tobouah, 05/05/2018

Figure 12. Sign post of Potatoseed farm in Oku.

Innovation in potato farming is also taking the dimension of introducing seed multiplication farms. This is a way of assuring

constant potato cultivation thus acting positively on food security. As a matter of fact, potatoes seeds have to be properly conserved because of they are easily subject to attacks [19]. These species are gradually becoming susceptible to late blight and other attacks. Large scale cultivation of these potato species therefore calls for an intensive pesticide spray to limit losses caused by both pests and pathogens. The most used mineral fertilizer is 20:10:10 followed by 12:6:20. Currently, 14:24:14 and 11:11:22 are being used. Results produced by IRAD researchers indicate that the best formulation of fertilizers for potato production is 120:180:100 NPK but it is scarcely used in Bui Division 
principally because of the fertile soil, and conducive cool climates suitable for cultivation [20]. Potato is a good source of protein. It has a favourable ratio of protein calories and is an important source of vitamins and minerals. Table 12 shows appropriate techniques for potato cultivation.

Table 12. Appropriate techniques for potato cultivation.

\begin{tabular}{|c|c|c|c|c|c|c|}
\hline Crop & $\begin{array}{l}\text { Land } \\
\text { preparation }\end{array}$ & Inputs & Planting & $\begin{array}{l}\text { Field } \\
\text { Maintenance }\end{array}$ & Harvesting & $\begin{array}{l}\text { Storage and } \\
\text { curing }\end{array}$ \\
\hline \multirow{3}{*}{ Potato } & $\begin{array}{l}\text {-Clear, rake and } \\
\text { stump the land. }\end{array}$ & $\begin{array}{l}\text {-NPK Fertilizer } \\
20: 10: 10, \\
12: 6: 20, \\
14: 24: 14, \\
11: 11: 22, \\
120: 180: 100\end{array}$ & $\begin{array}{l}\text {-Seed should have multiple } \\
\text { sprouts. -Planting distance is } \\
25-30 \mathrm{~cm} \text { apart, depth } \\
\text { between } 7-10 \mathrm{~cm} \text { Cover the } \\
\text { soil after planting }\end{array}$ & $\begin{array}{l}\text {-Molding after } 45 \text { days of } \\
\text { planting or when plant height is } \\
\text { at } 25 \mathrm{~cm} \text {. }\end{array}$ & $\begin{array}{l}\text {-Allow crop to } \\
\text { grow to full } \\
\text { maturity. }\end{array}$ & $\begin{array}{l}\text {-Wounded tubers } \\
\text { should be sorted } \\
\text { and removed. }\end{array}$ \\
\hline & $\begin{array}{l}\text {-Ridge } 100 \mathrm{~cm} \\
\text { apart }\end{array}$ & $\begin{array}{l}\text { CIMETHRINE } \\
\text { CIPECA }\end{array}$ & $\begin{array}{l}\text {-Apply fertilizers at a rate of } \\
120 \mathrm{~N}-180 \mathrm{P}-100 \mathrm{~K} / \mathrm{ha} \text {. }\end{array}$ & \multirow{2}{*}{$\begin{array}{l}\text {-Application of urea after first } \\
\text { molding. } \\
\text {-Molding two weeks after. } \\
\text {-Disease control from } \\
\text { germination. } \\
\text {-Spray with fungicides and } \\
\text { insecticides when symptoms } \\
\text { exist. } \\
\text {-Use bacterial wilt on viruses }\end{array}$} & $\begin{array}{l}\text {-Open ridges and } \\
\text { harvest. }\end{array}$ & \multirow{2}{*}{$\begin{array}{l}\text {-Clean and } \\
\text { disinfect the store } \\
\text { before harvesting. } \\
\text {-Sort seeds timely } \\
\text { till sprout. } \\
\text {-Store seeds in } \\
\text { diffused light } \\
\text { store. }\end{array}$} \\
\hline & $\begin{array}{l}\text {-Crest to crest } \\
\text { and } 20-25 \mathrm{~cm} \\
\text { height }\end{array}$ & & $\begin{array}{l}\text {-Fertilizer should be mixed } \\
\text { in the soil after application. } \\
\text {-Tubers placed in the soil } \\
\text { with sprouts up. }\end{array}$ & & $\begin{array}{l}\text {-Grade seeds into } \\
\text { various sizes } 0-10 \text {, } \\
11-15,16-25+\mathrm{mm} \text {, }\end{array}$ & \\
\hline
\end{tabular}

Source: Appropriate techniques for seed potato production, (March 2015)

\subsection{Vegetable and Spices Seed Nursery Techniques}

The most common way of seed nursery involves the use of tyres. The tyre is cut and filled with soil. When the quantity of seeds to be nursed is much, the farmer uses more than one tyre. The tyres contain different nursed species of vegetables as seen in the Figure.

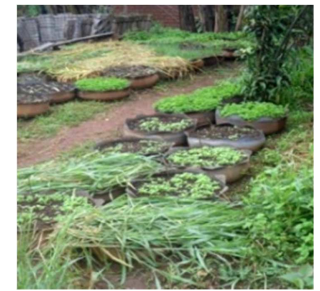

Source: Tobouah, 04/08/2018

Figure 13. Spices nursery in a tyre.

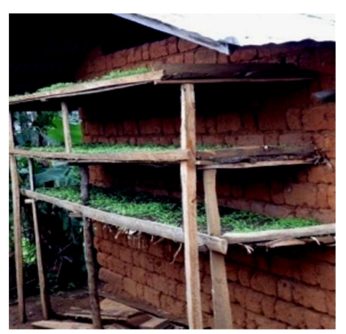

Source: Tobouah, 05/05/2018

Figure 14. Local tomato nursery technique on walls.

Innovations in tomato seed nursery involve the use of local materials [21]. In the past, seed nursery was done in tyres. Innovations in tomato seed nursery include the use of platforms prepared and attached to the walls of the house. Planks are used to suspend the nursed beds. This technique prevents the nursed tomato species from being damaged by fowls. Plate 4 above is an innovative way of nursing tomato seeds apart from the common technique of using a tyre.

\section{Conclusion}

Agricultural innovation practiced within Bui Division is a way of fine tuning farmers' efforts about crop growing. Hazardous agricultural practices are gradually being halted giving way to maximization of the available lands under cultivation thus fostering development from the proceeds obtained. This study focused on peasant resilience and stakes in crop cultivation within an unstable bio physical milieu. In order to attain results, several methods and analysis were carried out within the study area. This is a sustainable entry point in the introduction of agricultural innovations in farming communities which thereby heralds another resilient technique. In a nutshell, achieving high yields largely depends on peasant resilience, hard work spirit, local management skills, and above all the ability of the farmers to adapt to the bio-physical milieu. Farmers' efforts to improve on output were generally observed during field investigations. It is generally confirmed that the hope for the future in terms of food supply lies in the different resilient techniques adopted.

\section{Author Contributions}

This paper constitutes part of a PhD research carried by Dr. GodwillTobouahNyanchi, in the department of Geography, University of Yaoundé 1. Conceptualization, design of research instruments, data collection and writing is the original work of the corresponding author. The article manuscript was improved by review comments from Pr. Mbanga Lawrence Akei of the University of Bamenda, Cameroon and co authors from the University of Yaoundé 1. Their comments enriched this paper. 


\section{Conflicts of Interest}

The authors declare no conflict of interest.

\section{References}

[1] GODWILL TOBOUAH N. 2020, Agro Forestry Innovations and Their Implication on Development in Bui Division, North West Region of Cameroon, Ph.D Thesis, Department of Geography, University of Yaoundé 1, 426P.

[2] KIMING I. N, GODWILL TOBOUAH, MOYE ERIC, NKIENE V. A, NGHOBUOCHE F and MOR NOEL M, 2020, Climate Variability Impact and Adaptation: The Experience of Maize Farmers in Bui Division, North West Cameroon, International Journal of Environment, Agriculture and Biotechnology, 16P Available: https://ijeab.com/

[3] GODWILL TOBOUAH N., 2015, Agro Forestry Practices in Oku Sub-Division: An Impetus to Food Supply and Rural landscape Transformation. Masters Dissertation, Department of Geography, University of Yaoundé 1. 149P.

[4] GODWILL TOBOUAH N, KIMING I. N, NYUYKI B. B, AKONI I. N, NGEK G. N, 2020, Challenges of Rural Landscape Mosaic and Beautification in Oku, North West Region of Cameroon, International Journal of Science and Qualitative Analysis 1-7 http://www.sciencepublishinggroup.com/j/ijsqa

[5] BERINYUY BIME H., 1984, Production and Marketing of Foodstuffs in Bui-Division, Cameroon; An Effort in Rural Transformation, Doctorat de TroisiemeCycle, Department of Geography, University of Yaounde 1, 261P.

[6] WIRSIY E., B., 2013, Assessment of the Effectiveness of Biogas Slurry as Biofertilizer for Vegetable Gardening in Kumbo, Cameroon: Case of Solanum Scabrum, Department of Plant Biology, Master'sDisertation, Faculty of Science, University of Yaoundé I, 68P.

[7] HAWKINS R., and BRUNT, 1965, The Soils and Ecology of West Cameroon, Volume 1, FAO, Rome, 212P.

[8] KWESIGAF., and COER., 1994, The Effect of ShortTermRotation Sesbania Sesban Planted Fallows on Maize Yield. Forest Ecology and Management 67P.

[9] FAO 2011, The State of Food and Agriculture 2010-2011: Women in Agriculture - Closing the Gender Gap for Development. UN Food and Agriculture Organization, Rome.

[10] MBANGA L., A., and NGALA H., N., 2015, Participation in
Development: A Panacea for Improving Rural Livelihood in Cameroon, published in ELONG G., J., TCHAWA P., MOUPOU M., 2015, Participation et Developpement Rural au Cameroun, Edition Cle Yaounde, 322P.

[11] GODWILL TOBOUAH, NCHAMCHAM Olive, 2019, Common Initiative Groups (CIGs) Enhancement inAgricultural Production Oku, Cameroon, International Journal of Sustainable Development Research, 8P. 2019; 5 (3): 71-78, http://www.sciencepublishinggroup.com/j/ijsdr

[12] KABWE G., 2010, Uptake of Agro forestry Technologies among Smallholder Farmers in Zambia. Ph.D Thesis in Geography, Lincoln University USA, 246P.

[13] WORLD BANK 2007, World Development Report 2008: Focuson a Declining Rural Poverty, as a Key Factor in Aggregate Poverty Reduction. World Bank: Washington D. C.

[14] WORLD BANK 2012, Agricultural Innovation Systems, An Investment Sourcebook, 684PP.

[15] ENCHAW G., B., 2009, An Assessment of Conservation Strategies in the Management of Natural Resources in KilumIjim Forest Project Area (NWR), Ph.D Thesis, Department of Geography, University of Yaoundé 1, 383P.

[16] MBANGA L., A., 2010, An Analysis of Community Participation in the Rural Development Process of Ngoketunjia Division in the North West Region: A Geographical Approach. Ph.D Thesis, Department of Geography, University of Yaoundé 1. 421P.

[17] CALESTOUS JUMA and KATHERINE G.,, 2015, Taking Root: Global Trends in Agricultural Biotechnology. Discussion Paper 2014-07, Belfer Center for Science and International Affairs, Cambridge, Mass.: Harvard University, 28P. www.belfercenter.org/global.

[18] Cameroon: Growth and Employment Strategy Paper, 2009, $96 \mathrm{P}$.

[19] KAH E., F., and NDIFOR D., A., 2012, Mapping of Local Construction Materials for the North West Region of Cameroon 15p.

[20] Liste des Pesticides Homologues au Cameroun: 31 Juillet 2013, 40P.

[21] MBANGA L., A., 2015, Regional Institutions in Rural Council Area Development in the North West Region, Cameroon, Journal of Sustainable Development, Vol. 8, No. 1, PP 93-107. 